Models for the Safety Analysis of RW Disposal Facilities

\title{
NUMERICAL SAFETY ASSESSMENT AND OPTIMIZATION OF DECISIONS ON RADIOACTIVE WASTE DISPOSAL AND NUCLEAR DECOMMISSIONING: TRENDS, NEEDS, OPPORTUNITIES
}

\author{
Linge I. I. ${ }^{1}$, Utkin S. S. ${ }^{1}$, Svitelman V. S. ${ }^{1}$, Deryabin S. A. ${ }^{2}$ \\ ${ }^{1}$ Nuclear Safety Institute of the Russian Academy of Sciences, Moscow, Russia \\ ${ }^{2}$ State Corporation "Rosatom", Moscow, Russia
}

Article received on April 9, 2020

The paper focuses on numerical safety assessment and decision-making optimization under radioactive waste disposal and nuclear decommissioning projects. The paper demonstrates the industry needs for an up-to-date software and the corresponding capabilities of the computational framework being developed. The article also explores its development potential in light of modern IT trends.

Keywords: radioactive waste, safety assessment, computational codes, numerical modelling, RW disposal, nuclear decommissioning .

\section{Background}

The development and implementation of national computational tools, including codes or computer software [1] is currently viewed as a strategic task in the deployment of import-independent Russian technologies.

Numerical studies are considered as a key and often the only tool supporting safety assessments in the field of radioactive waste (RW) management [2]. The latter is explained by the fact that due to the complexity of the considered systems and the number of safety-important processes, in some cases relevant experiments are either impossible in principle or the possibilities for obtaining experimental data are significantly limited (being considered as highly time- and resource-consuming).

Thus, an evident increase in the number of facilities at the final stages of the nuclear fuel cycle
(NFC), providing for the development of decommissioning designs and establishment of new tasks set to demonstrate the safety and effectiveness of the selected RW conditioning and disposal solutions, ipso facto requires the development and implementation of new computer codes.

Moreover, it should be taken into account that in 2018 important amendments were introduced to the Federal law On the Use of Atomic Energy [3] stating the requirement on the state certification of computer software in case if it's used to demonstrate the safety of nuclear facilities. In this regard, provisions of some regulations, for example [4-6], allow for an expanded interpretation - as framework requirements to a system of calculation, analytical and experimental long-term safety justification. 
Continuous harmonization of federal regulatory framework with international requirements and recommendations is seen as yet another factor. Thus, the principles of building confidence in its results and a comprehensive system of argumentation [7], which are viewed as quite relevant for the purposes of this article and still haven't been fully implemented under national safety justification practice, are partially reflected, for example, in paragraphs 249, 250, 253 of the Requirements on the Content and Structure of a Safety Analysis Report on DDF RW [6] indicating the requirement for the application of various models and methods, accounting uncertainties, etc.

Obviously, requirements elaborated to a certain level of detail are expected to be introduced into the long-term safety demonstration practice addressing other types of disposal facilities as well, including specific ones (for example, containing reactor graphite), as well as nuclear legacy facilities assigned with the status of disposal facilities for non-retrievable RW and RW disposal facilities.

Already now, a wide range of international recommendations is being introduced, in particular, those relevant for DDF LRW under the Program of Design and Experimental Studies ... approved by the State Atomic Energy Corporation Rosatom and Rostekhnadzor, to provide compliance of Russian LRW DDF long-term safety demonstration approaches and procedures with relevant international standards [8]. The latter also implies a reasoned analysis of safety-relevant impacts of about 250 categories of features, events, and processes [9] (and this number at least doubles if one proceeds to the consideration of individual factors that are viewed as relevant for particular disposal designs).

Practical implementation of the entire set of requirements implies that specific software tools are available to support the modeling of all relevant processes, comprehensive analysis, adequate consideration of uncertainties, including those associated with the construction of the facility, the state of engineered safety barriers and the geological environment. Operational adaptation to the newly obtained data (results of experiments, monitoring, refinement of structure geometry, for example, by laser scanning methods, etc.) is also considered as an essential aspect.

All of the above prompts industry-wide development of software that would meet the regulatory requirements based on "one step ahead" principle and functional needs to address most important practical tasks identified by SC Rosatom and the scientific community being considered as relevant for the long-term safety of RW management $[10,11]$.

\section{Specific aspects of numerical modeling} for DDF RW safety assessment purposes

Global experience shows [12-15] that DDF RW development is an extremely difficult task requiring long-term and large-scale efforts, including the development of scientific and engineering background and tools, optimization of the disposal system characteristics, long-term safety assessment and demonstration.

Large time frames associated with the implementation of such projects and the multidisciplinary nature of the tasks addressed suggests that a modular and iterative approach should be inevitably followed [16] (Figure 1). Modularity (breakdown into to simpler sub-tasks for greater level of detail) provides flexibility and allows to check whether the results obtained actually meet the requirements of various stakeholders. Iterativeness implies that the level of detail and confidence in the resulting safety assessments increases while progressing from one stage of research to another, along with the accumulation of necessary data, development of models and methods, etc., and ultimately allows to make an adequate decision on the safety and feasibility of the project.

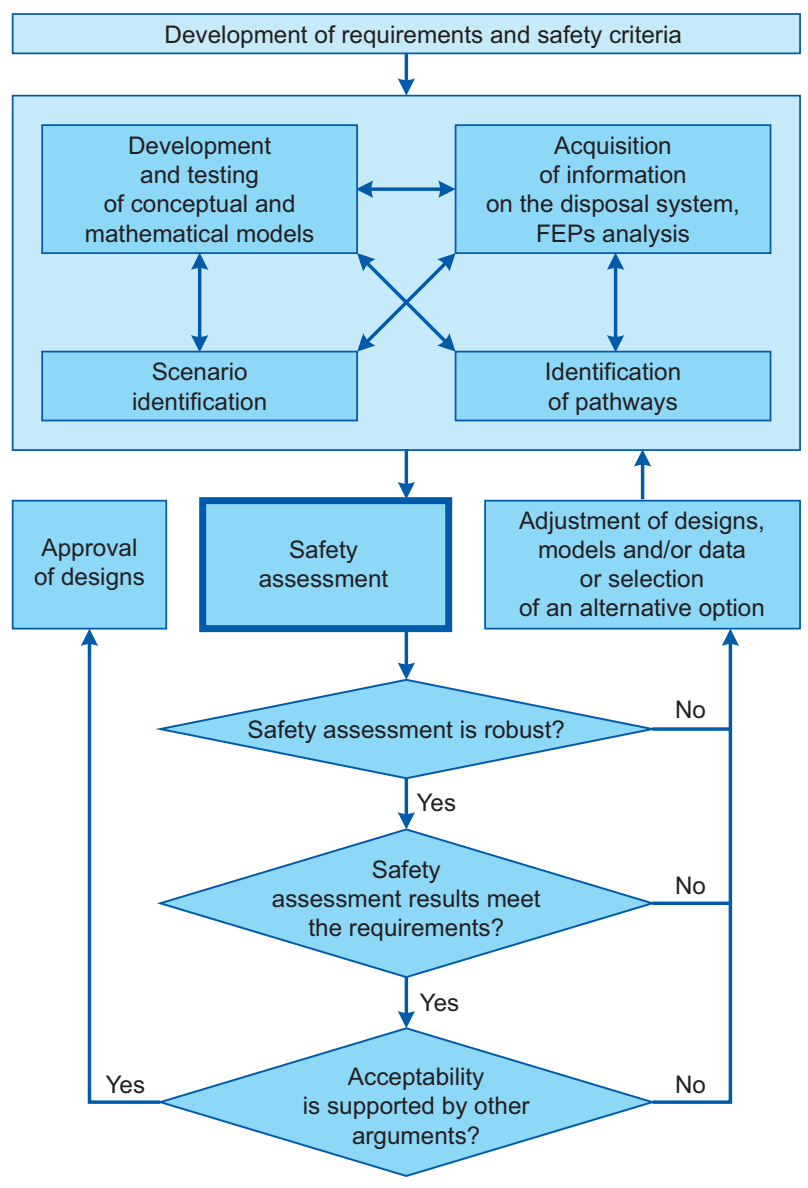

Figure 1. Workflow under the iterative approach addressing safety demonstration task [16] 
Multi-barrier protection is viewed as the key principle of DDF RW long-term safety suggesting that radionuclides are contained within the facility structure and their migration is slowed down due to multiple mechanisms acting at different time scales provided both by the host rock and the elements of the engineered barrier system. Commonly safety functions for each element of the disposal system are identified and justified [17].

Apparently, the combination of safety functions implemented by individual barriers is quite specific and is associated with the site's specific features, the disposal concept, acceptability criteria, requirements of interested parties, etc., which makes it somewhat unique [18].

Since many of the computational problems have already been solved not only under similar projects, but also in related fields of knowledge, it is obvious that this experience (and, in certain cases, appropriate software) can be applied, of course, suggesting proper adaptation to specific aspects of a particular project.

Specific software tools are selected based on many factors. One of them is the Best Available Techniques approach recommended by OECD NEA [19] and the European Commission [20], which is also enshrined in the regulations of some countries [21, 22] considering all aspects of DDF RW construction and safety demonstration, also including the computer codes applied.

As applied to computer codes, Best Available Technique refers to models and numerical methods applied, and in some cases already available "best solution" can be integrated into the information system "as it is", in the form of an already available software tool. However, the costs of integration into a system and its adaptation for the tasks are often greater than the costs (in the broad sense) for the development of a new software tool that implements the same "best solution", but takes into account the need of providing interaction with available calculation tools, databases and other elements of the information environment under DDF RW designs.

All the above suggests that decomposition of a computational safety assessment problem into individual elements carried out in specific software tools can be implemented in different ways. Table 1 presents some examples of such decomposition already implemented under certain disposal projects abroad.

Under the long-term safety demonstration of Russian DDF RW, some focus areas of research addressing the development of the following models were stated under the integrated research program [26], namely, its part concerning numerical assessments:
Table 1. Computer codes used in some DDF RW projects abroad [23-25]

\begin{tabular}{|c|c|c|}
\hline Posiva [23] & SKB [24] & NAGRA [25] \\
\hline \multicolumn{3}{|c|}{ Assessment of RW characteristics } \\
\hline ORIGEN-S & Ecolego & $\begin{array}{c}\text { STMAN (SPENT, } \\
\text { STRENG, STALLION) }\end{array}$ \\
\hline \multicolumn{3}{|c|}{ Processes in EBS } \\
\hline $\begin{array}{l}\text { CODE BRIGHT, PHREEQC, } \\
\text { TOUGHREACT (TOUGH2), } \\
\text { REPCOM, GoldSim RT }\end{array}$ & $\begin{array}{c}\text { Comsol Multiphysics, } \\
\text { PHREEQC, PHAST, } \\
\text { Ecolego }\end{array}$ & $\begin{array}{c}\text { STMAN (SPENT, } \\
\text { STRENG, STALLION), } \\
\text { VPAC }\end{array}$ \\
\hline \multicolumn{3}{|c|}{ Hydrogeological processes } \\
\hline $\begin{array}{l}\text { ConnectFlow, } \\
\text { COMSOL Multiphysics, } \\
\text { FASTREACT, PHREEQC, } \\
\text { FTRANS, MARFA }\end{array}$ & $\begin{array}{l}\text { DarcyTools, } \\
\text { Ecolego }\end{array}$ & VPAC, PICNIC \\
\hline \multicolumn{3}{|c|}{ Thermal transfer and stress-strain state } \\
\hline $\begin{array}{l}\text { 3DEC, Fracod2D, } \\
\text { ABAQUS, PASULA, } \\
\text { ANSYS }\end{array}$ & 3DEC, ADINA & - \\
\hline \multicolumn{3}{|c|}{ Uncertainty and sensitivity assessment } \\
\hline GoldSim & Ecolego & - \\
\hline \multicolumn{3}{|c|}{ Biosphere and dose calculations } \\
\hline $\begin{array}{c}\text { ArcGIS, Pandora (MATLAB), } \\
\text { Ecolego, ERICA }\end{array}$ & $\begin{array}{l}\text { ArcGIS, Ecolego, } \\
\text { MIKE SHE }\end{array}$ & TAME, SwiBAC \\
\hline
\end{tabular}

radionuclide leaching (changes in the properties of RW materials);

- groundwater seepage and migration of radionuclides in the EBS system and the geological environment;

- stress-strain state of the rock mass and the EBS system;

- long-term changes in the geological setup and evolution of geological processes;

- evolution of EBS materials;

- radiation exposure of population and the environment;

- long-term changes in hydrological, hydrodynamic and hydrogeochemical conditions, natural-landscape characteristics and climate of the siting area, as well as in human activities and biota.

Figure 2 provides a broad view of the models. Figure 3 provides an example of a more detailed representation of modeled processes relevant for the near-field of a disposal facility.

It should be specifically noted that integrated modeling of all safety-important processes is still viewed as a challenge for the scientific and technical community [27].

The latter is partially explained by the need for a deeper understanding of the variety of physical, chemical and biological processes affecting the distribution of radionuclides, as well as the need for multivariate calculations during the development 
System of models addressing radionuclide transfer

Uncertainty and sensitivity assessment

Figure 2. Relations between the models used for long-term DDF RW safety demonstration purposes

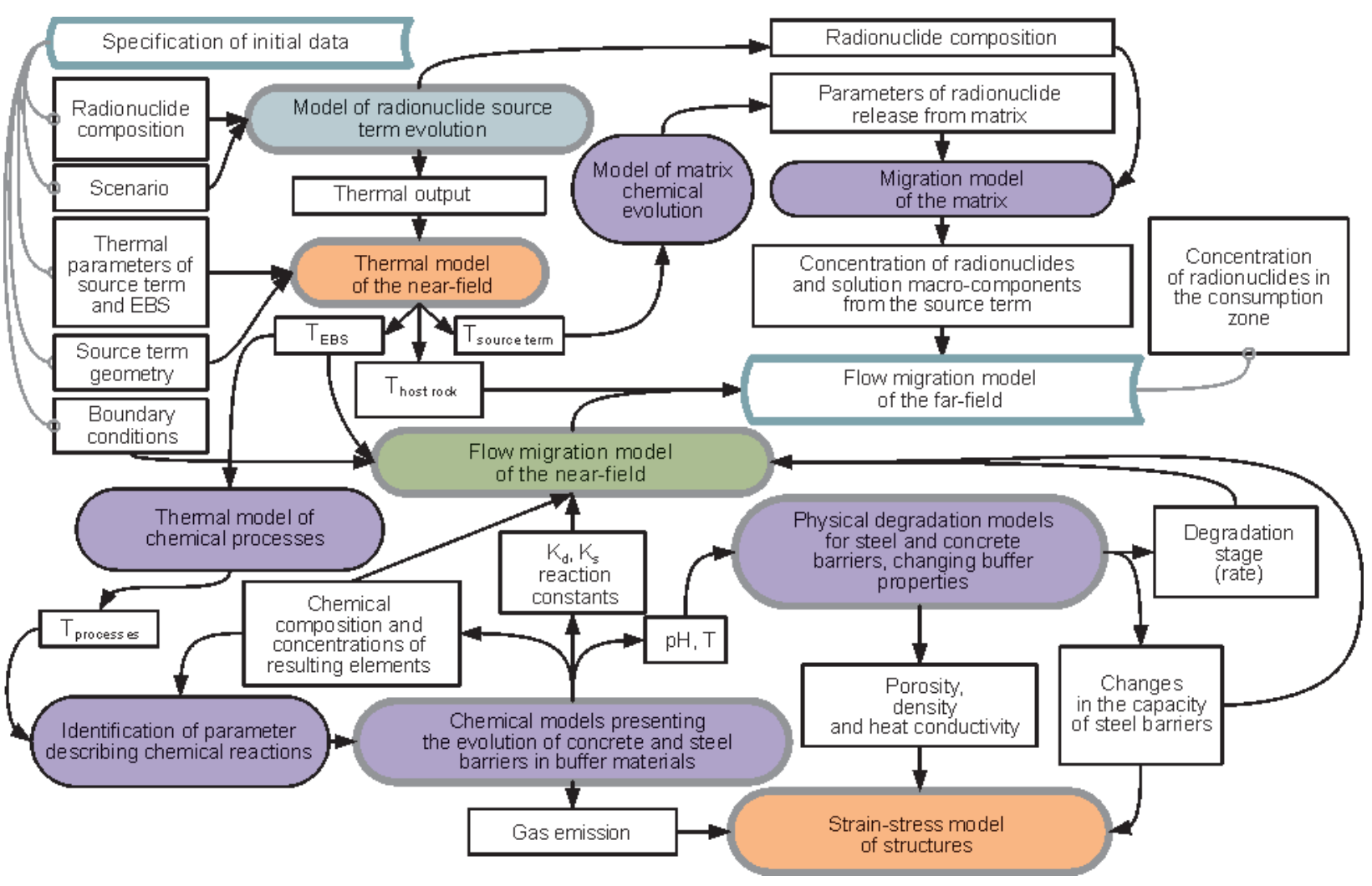

Figure. 3. An example of interrelated models for processes occurring in the near-field of DDF RW

of various long-term DDF RW evolution scenarios and varying the values of input parameters required for uncertainty and sensitivity assessments.

The complexity of interrelated calculations is basically driven by a wide physical (from micrometers to describe local processes of corrosion, radiolysis, other chemical and biological reactions, to kilometers to describe the long-term distribution of radionuclides in the geological environment) and time ranges (from tens to millions of years).

Thus, for example, meshing used to visualize one insulating container contains about 600 thousand finite elements (Figure 4a), whereas the one representing the DDF NKM (Figure $4 \mathrm{~b}$ ) with 462 wells designed for RW emplacement requires a grid of more than 30 million cells even if a simplified form is accepted (with one well presented in detail and rough breakdown of the rest).

Although at early stages, iterative approach allows and even recommends to use simple models and available calculation tools, detailed three-dimensional models implemented in modern precision calculation software are required further to take into account all design-specific factors in addition to accurate initial data. In this case, the development of purpose-tailored software tools based on well-established calculation methods is often seen as more flexible and effective option than the refinement of codes used in similar projects or related fields. 

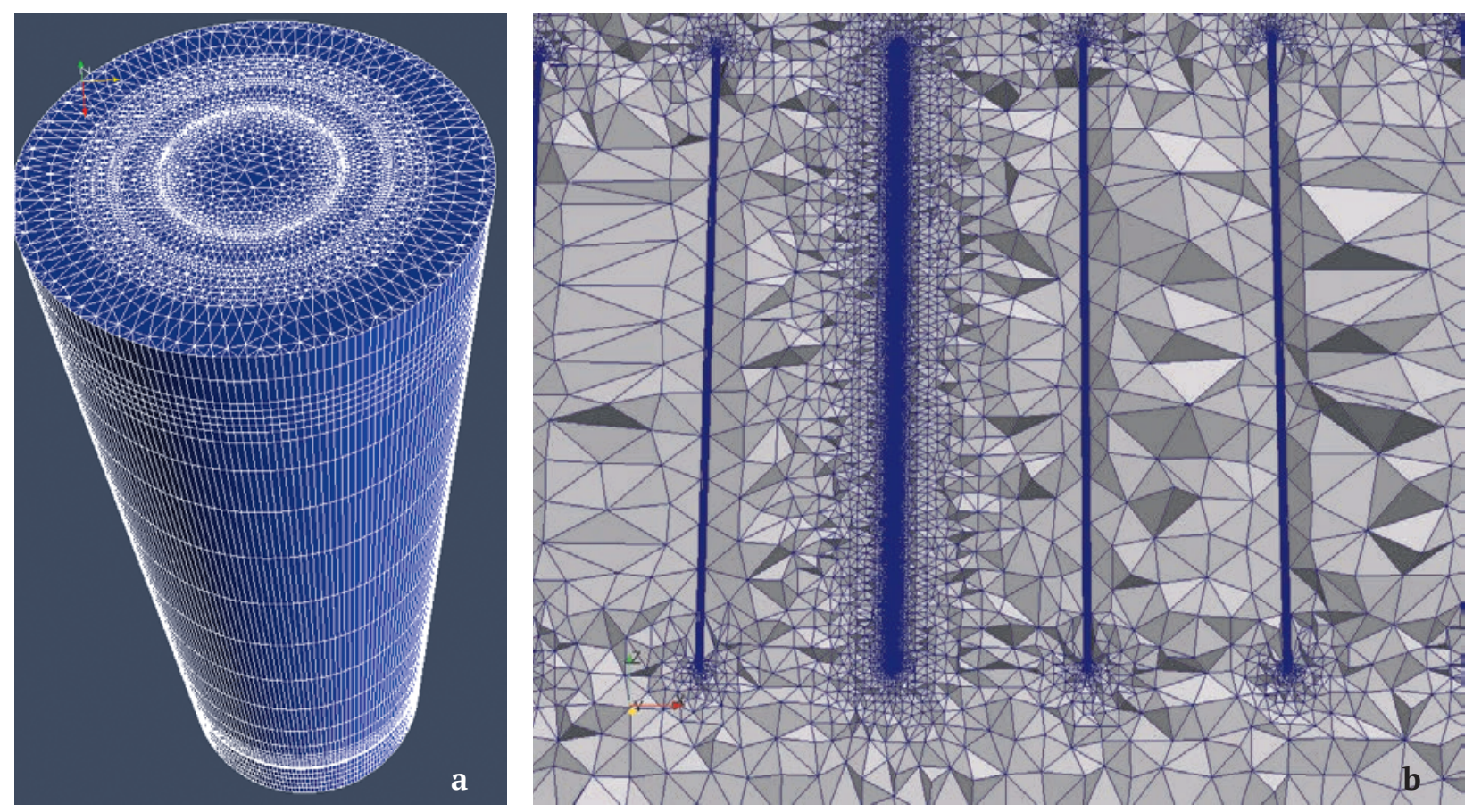

Figure 4. A grid view of an insulating container (a)

and a fragment of a disposal section containing a number of wells designed for RW emplacement (b)

Numerical assessment needs in decommissioning

Another specific and extensive class of tasks prompting the development of modern computational tools is related to the optimization of nuclear decommissioning solutions. Currently, this issue is more and more intensively discussed by the international community. Such interest is particularly explained by a large number of facilities being at the final stages of the NFC, required planning decommissioning already during the design development of new facilities and some cases when the decommissioning had to be started beforehand [28].

Practical solutions are worked out, which includes [29-31] radiological characterization of the actual state, dismantlement scenario optimization, assessment of radiation exposure to humans and biota, assessing the potential further recycling of radioactively contaminated metals in the nuclear industry. Numerical simulation needs required to address decommissioning tasks are schematically shown in Figure 5.

\section{Developed system of codes}

Until recently, foreign software was mainly applied for radiation and environmental safety demonstration purposes, for example: chamber models Amber, Ecolego applied to predict radionuclide migration in the geosphere and the effectiveness of physical safety barriers; three-dimensional codes Modflow, TOUGH2, etc. - for hydrogeological calculations; Microshield - to assess the radiation setup; ANSYS - for strength calculations, HEC-RAS - for hydrological modelling, etc.

In the currently available list of software tools certified by Rostekhnadzor, less than $3 \%$ are related to the safety demonstration of nuclear legacy facilities and RWDF, as well as addressing tasks associated with the final stage of the life cycle (FSLC) [32].

In 2014-2015, under the efforts aimed at highlighting the priorities for the development of science and technology, scientific and technical councils of SC Rosatom (in particular, with regard to the considered issues - STC meeting No.10 held on March 12, 2015), current trends in the development of software and mathematical models were identified, including:

- development of detailed three-dimensional models of nuclear facilities;

- development of software tools enabling calculations based on actual data supporting safety assessments;

- integration of large-scale computational systems and models with computer-aided design system (CAD);

- development of computational methods aimed at optimizing the computational process (parallel computational algorithms, adaptive unstructured grids).

Compulsory accounting of these trends in the development of software tools designed to support long-term safety assessments was stated in the R\&D on the Development of a Hands-on 


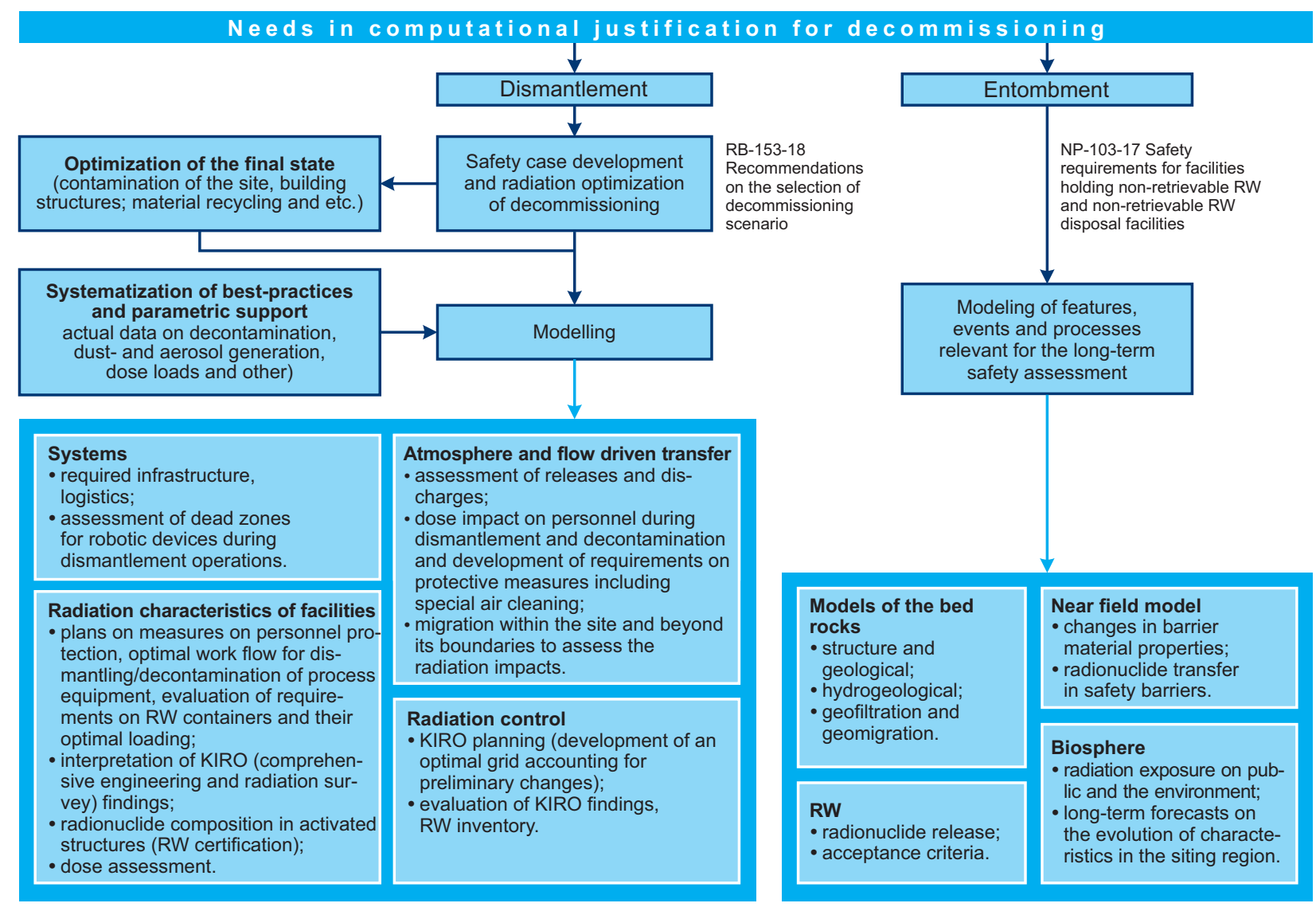

Figure 5. Numerical modeling needs allowing the optimization of decommissioning solutions

Methodology for Comprehensive Safety Demonstration of Legacy Facilities, RW Disposal Facilities, Including the Development and Implementation of a Code System and Calculation and Forecasting Complexes that has been implemented since 2016.

The system under development constitutes to a complete set of modern computer codes (calculation and prognostic complexes or CPC) (Table 2) designed for safety demonstration purposes, which should provide for coupled simulation of thermohydro-mechanical, chemical, biological processes being relevant for the long-term safety [33-36]. To simulate processes in the near and far fields, detailed grid models of various scales are being developed. Detailed consideration of safety barriers, disposal matrices and the actual heterogeneous structure of the geological environment necessitates calculations on grid models composed of many millions of cells. Therefore, codes are actively evolving to account for parallel computing algorithms, adaptive unstructured grids and the use of high-performance computing systems. According to international requirements and best practices, the codes being developed enable to couple the modeling of all processes with sensitivity and uncertainty assessments [37].
Progress in the development of computer code system supporting radiation and environmental safety demonstration for nuclear legacy and radioactive waste disposal facilities was discussed, in particular, at the meeting of SC Rosatom's STC No. 10 held on October 24, 2018. Priority tasks were considered, including those associated with attaining an adequate maturity level of the software tools required for their expert examination, as well as the need for a coordination meeting that would join the developers and users.

To date, a four-year stage has been completed, following which pilot versions of all codes listed above have been developed, as well as necessary supporting documentation (user manuals, model manuals, verification reports). Within three years, all CPCs will be submitted for certification. Pilot versions are applied in a test mode by operating, design and expert organizations, including JSC FCS \&HT SNPO Eleron, VNIPIET; AECC; RIAR; ISC Atomenergoproekt; ISC GSPI; STC NRS.

In 2019 alone, a total of 17 pieces of intellectual property were registered, 25 articles and preprints were published on the subject of computer codes development, relevant findings were presented at 40 international and Russian scientific conferences and workshops. 
Table 2. The main characteristics of the computational tools being under development

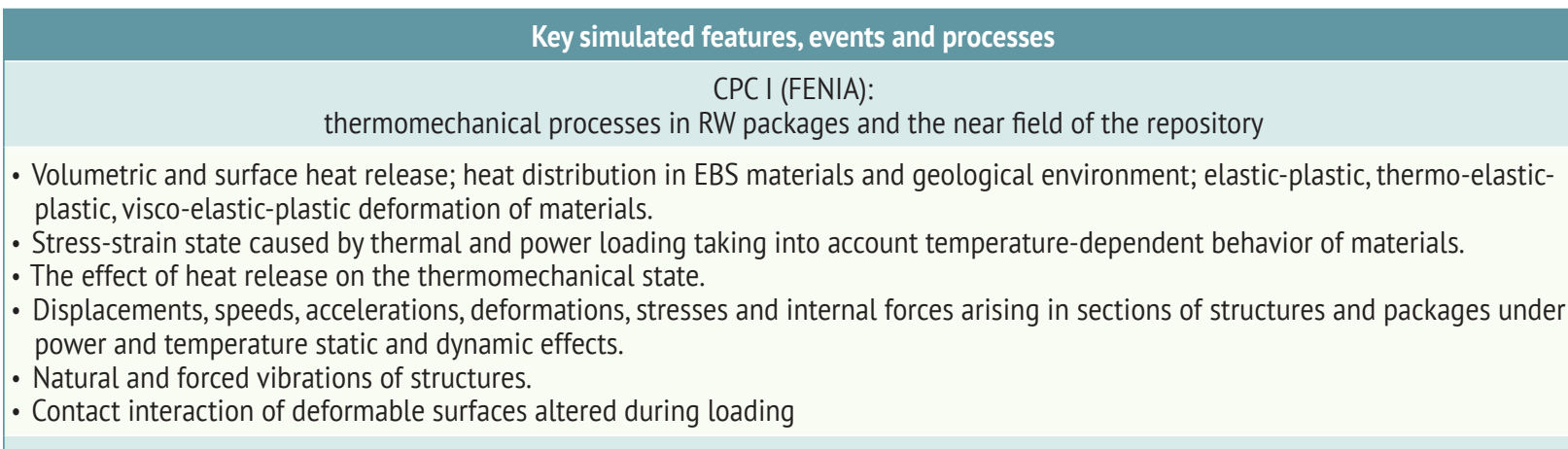

\section{CPC B (DESTRUCT):}

engineering and chemical aspects associated with radionuclide migration in the near field, including engineered barriers [34]

- Materials of insulating containers, their physical, chemical and biological characteristics at the time of disposal.

- Mechanical, thermal, chemical and biological processes affecting the waste, containers, sealings and other EBS elements.

- Change in properties (density, porosity, permeability) and matrix integrity (glass, cement, etc.).

- Migration of radionuclides through EBS.

- Changes in sorption-waterproofing, water conductivity and EBS properties; influence of thermal processes on the intensity of chemical reactions and physical processes; effect of pore formation on transfer modes in aqueous phase and displacement of pore water.

- Occurrence and accumulation of key dose-contributing radionuclides.

- Absorption of water by buffer material (changes in humidity, porosity, flow rate of the transport aqueous medium)

$$
\begin{aligned}
& \text { CPC B (RELTRAN): } \\
& \text { gaseous distribution of radionuclides [38] }
\end{aligned}
$$

- Transfer of radioactive and chemical substances in the atmosphere with gas, steam, suspension of fine particles or aerosols: convection, turbulence and diffusion; dispersion; wet and dry precipitation; suspends in the air; wind-blown migration of sedimentary material; interaction of sediment, water and gases in the atmosphere.

- Gas leakage from container, gas emission, gas flows through the buffer and backfill.

- Multiphase movement of contaminants and their spread with gases, gas flows in the near and far fields

\section{CPC C (CADAM):}

contaminant transfer in surface water bodies [39]

- Surface runoff.

- Topography of the bottom and shores, erosion.

- Stratification and wind mixing.

- Water level fluctuations.

- Wetlands.

- Chemical composition of surface waters.

- Sedimentation of suspensions, resuspension and sediment transport

\section{CPC D (KORIDA):}

radiation characteristics of nuclear facilities, radioactive waste and spent nuclear fuel [35]

- Transfer of neutron, photon and electron radiation.

- External exposure of personnel taking into account the evolution of source terms and safety barriers, in particular, during the dismantlement of structures and radioactive waste disposal.

- Changes in the composition of materials during neutron irradiation due to activation, fission, transmutation and radioactive decay.

- Energy release during HLW and SNF cooling.

- Characteristics of radiation sources within geometric spaces limited by EBS.

- Radiogenic near-field evolution

$$
\begin{aligned}
& \text { CPC C (GeRaV.2): } \\
& \text { radionuclide transfer in different geological environments [36] }
\end{aligned}
$$

- Filtration under pressure and non-pressure, as well as unsaturated conditions, two-phase filtration (liquid-gas).

- Advection-dispersion-diffusion transport of radionuclides, chemically active and neutral impurities in porous and fractured media.

- Equilibrium and kinetic chemical interactions in a solution-rock system.

- Radioactive decay of migrating nuclides.

- Density convection.

- Transfer in dual porosity media.

- Flow of solutions with variable viscosity.

- Transfer of substances in colloidal form.

- Interaction of groundwater and surface water.

- Sorption with dynamic distribution coefficients 
Second version of geofiltration-geomigration code GeRa/V2 was submitted for certification. This version, compared to the first one, includes the following new models: transfer in media with double porosity; heat transfer and heat convection; dependence of solution viscosity on temperature and impurities concentration; two-phase filtration; coupled filtration and surface runoff processes.

Development of a software and hardware dose assessment complex for human and biota accounting for all possible exposure pathways associated with the radioactive contamination of water bodies has started. It's expected that the software tool will comply with all Russian requirements and international recommendations and considering its functional capacities, such a complex will be for the first time ever submitted for certification next year.

\section{Development trends}

The state-of-art in the development of the code system demonstrates its exceedance over the available certified software tools considering the completeness of the processes under consideration proving for a wider scope of their application.

The system of computer codes and databases constituting to the practical methodology should provide a service for numerical demonstration of long-term safety and optimization of RW disposal and decommissioning solutions, including issues associated with siting, design development, construction, operation, reconstruction, closure, RW management (transportation, conditioning, storage, disposal) presented as justifications of conceptual solutions at the pre-design development stage, permanent models and digital twins, as well as tools for periodic safety assessment performed at later stages. At the same time, both the regulatory framework and modern IT capabilities suggest that corresponding calculations should be based both on deterministic and probabilistic approaches.

Specific aspects of tasks addressed in the field of computational and experimental safety demonstration (in particular, given large forecasting time scales, heterogeneity and significant amount of information that must be taken into account, the large number of specialists involved) are associated with several trends in the development of computing systems.

A case in point is a separate work package dealing with information, data and knowledge management. It should be noted that similar challenges are being actively discussed within a big number of scientific and technical fields, although in the case of legacy facilities and RWDFs, the need for long-term preservation of information being directly related to their safety introduces its own specifics. Therefore, under foreign and international projects, both general methodological approaches (what and how to preserve) and specific software solutions are developed: knowledge bases, best practice databases, archives of source data and research findings, tools for their analysis, etc. [40].

Another trend provides for the integration of three-dimensional numerical models, purpose-designed databases, geographic information systems, etc. Consolidated information on various aspects of the subject area and its real time acquisition is in demand, for example, in decision support systems. So that decision-makers could quickly navigate in large information space, modern interactive interfaces are developed for such systems, including those applying virtual and augmented reality technologies [28].

Another trend is a gradual change in the paradigm associated with the positioning of calculation systems, which was also prompted not only by the specifics of the tasks to be solved, but also by the digital transformation of the nuclear industry and the economy on the whole, as well as the development of supercomputer and network technologies. This trend is based on the fact that computer codes being considered as products detached from their developers, but nevertheless requiring hardware and software adjustment, training and technical support, will become a digital service provided upon request to a remote user. The opportunities for performing multivariate calculation complexes on a single supercomputer platform [41] clearly complying with technical requirements, provided with all the necessary databases, knowledge and with a support provided by high-level experts provides both a fundamental improvement in the quality and a similar drastic cost reduction.

\section{References}

1. Poryadok provedeniya ekspertizy programm dlya elektronnykh vychislitelnykh mashin, ispolzuemykh $\mathrm{v}$ tselyakh postroeniya raschetnykh modeley protsessov, vliyayushchikh na bezopasnost ob"ektov ispolzovaniya atomnoy energii i (ili) vidov deyatelnosti v oblasti ispolzovaniya atomnoy energii : utv. prikazom Federalnoy sluzhby po ekologicheskomu, tekhnologicheskomu i atomnomu nadzoru ot $30 \mathrm{iyu}-$ lya 2018 g. № 325. [The procedure for the examination of programs for electronic computers used to build computational models of processes that affect the safety of nuclear facilities and (or) types of activities in the field of atomic energy use: approved. Order of the Federal Service for Ecological, Technological and Nuclear Supervision of July 30, 2018 No. 325]. 
2. Scott E. M. (ed.). Modelling radioactivity in the environment. - Elsevier, 2003. 438 p. ISBN: 9780080536651.

3. Ob ispolzovanii atomnoy energii : federalnyy zakon ot 21 noyabrya 1995 g. No. 170-FZ [On the Use of Atomic Energy : Federal Law of 21 November 1995 No. 170 - FZ.

4. NP-055-14. Zakhoronenie radioaktivnykh otkhodov. Principy, kriterii i osnovnye trebovaniya bezopasnosti [Radioactive Waste Disposal. Principles, Criteria and Main Safety Requirements].

5. NP-069-14. Pripoverhnostnoe zahoronenie radioaktivnyh othodov. Trebovaniya bezopasnosti [NearSurface Disposal of Radioactive Waste. Safety Requirements].

6. NP-100-17. Trebovaniya $k$ sostavu $i$ soderzhaniyu otcheta po obosnovaniyu bezopasnosti punktov zahoroneniya radioaktivnyh othodov [Requirements on the Contents and Structure of Safety Analysis Reports for Radioactive Waste Disposal Facilities].

7. Zahoronenie radioaktivnyh othodov. Konkretnye trebovaniya bezopasnosti [Disposal of radioactive waste Specific safety requirements]. № SSR-5. Vienna: IAEA, 2011. - ISBN 978-92-0-420010-2.

8. Dorofeev A. N., Saveleva E. A., Utkin S. S., Ponizov A. V. et al. Evolyutsiya obosnovaniya dolgovremennoy bezopasnosti PGZ ZHRO [Evolution in the Safety Case for Liquid Radioactive Waste Geological Repositories]. Radioaktivnye othody - Radioactive Waste, 2017, no. 1, pp. 56-65.

9. NEA/RWM/R(2019)1. Radioactive Waste Management and Decommissioning. International Features, Events and Processes (IFEP) List for the Deep Geological Disposal of Radioactive Waste. Version 3. Paris: OECD, 2019.

10. Reshenie problem, otmechennykh na pyatom Soveshchanii. - V kn.: Pyatyy natsionalnyy doklad Rossiyskoy Federatsii «O vypolnenii obyazatelstv, vytekayushchikh iz Ob"edinennoy konventsii o bezopasnosti obrashcheniya s otrabotavshim toplivom i o bezopasnosti obrashcheniya s radioaktivnymi otkhodami» k shestomu Soveshchaniyu Dogovarivayushchikhsya storon po rassmotreniyu natsionalnykh dokladov v ramkakh Ob"edinennoy konventsii o bezopasnosti obrashcheniya s otrabotavshim toplivom i o bezopasnosti obrashcheniya $\mathrm{s}$ radioaktivnymi otkhodami [Addressing the Challenges Pointed Out at the Fifth Review Meeting. - In: The fifth national report of the Russian Federation on compliance with the obligations of the joint convention on the safety of spent fuel management and the safety of radioactive waste management]. Austria, Vienna, 21 May -1 June 2018. pp. 139-140.

11. Bolshov L. A., Linge I. I., Sarkisov A. A., Utkin S. S. Praktika i zadachi nauchnogo obespecheniya rabot po yadernomu naslediyu [Practice and Problems of Scientific Support for Nuclear Legacy Work]. Atomnaya energiya - Atomic Energy, 2016, vol. 120, no. 4, pp. 252-258.

12. Nuclear Energy Agency, Radioactive Waste Management Committee. The Environmental and Ethical Basis of Geological Disposal of Long-lived Radioactive Wastes. - Paris: OECD, 1995.

13. Tsebakovskaya N. S., Utkin S. S., Linge I. I., Pron I. A. Zarubezhnye proekty zakhoroneniya OYAT i RAO. Chast I. Aktualnoe sostoyanie proektov sozdaniya punktov glubinnogo geologicheskogo zakhoroneniya v evropeyskikh stranakh: Preprint № IBRAE-2017-03 [Foreign SNF and RW disposal projects. Part I. The current condition of the projects of deep geological disposal facilities in European countries]. Preprint of IBRAE no. IBRAE-2017-03. Moscow, IBRAE RAN Publ., 2017. 35 p.

14. Tsebakovskaya N. S., Utkin S. S., Konovalov V. Yu. Zarubezhnye proekty zakhoroneniya OYAT i RAO. Chast II. Aktualnoe sostoyanie proektov sozdaniya punktov glubinnogo geologicheskogo zakhoroneniya v SSHA, Kanade i stranakh Aziatskogo regiona: Preprint № IBRAE-2017-04 [Foreign SNF and RW disposal projects. Part II. Current condition of the projects of deep geological disposal in the USA, Canada and Asian region]. Preprint of IBRAE no. IBRAE-2017-04. Moscow, IBRAE RAN Publ., 2017. 41 p.

15. Tsebakovskaya N. S., Utkin S. S., Pron I. A., Konovalov V. Yu. Zarubezhnye proekty zahoroneniya OYAT i RAO. Chast III. Zarubezhnyj opyt sozdaniya i ekspluatacii podzemnyh issledovatel'skih laboratorij [Internetional Experience in Deep Geological Disposal of SNF and RW. Part 3. International experience in development and operation of underground research laboratories]. Preprint IBRAE no. IBRAE-2017-12. Moscow, IBRAE RAN Publ., 2017. 34 p.

16. Geological Disposal Facilities for Radioactive Waste, Specific Safety Guide No SSG-14. IAEA Safety Standards, Vienna: IAEA, 2011.

17. International Experience in Safety Cases for Geological Repositories (INTESC): Outcome of the INTESC Project : Publication 6251. Paris: OECD NEA, 2009.

18. Chapman N., Hooper A. The disposal of radioactive wastes underground. Proceedings of the $\mathrm{Ge}$ ologists' Association, 2012, vol. 123, no. 1, pp. 46-63. DOI: $10.1016 /$ j.pgeola.2011.10.001.

19. Galson D. A., Bailey L. Performance assessment and the safety case: Lessons from recent international projects and areas for further development. 2014. NEA-RWM-R -2013-9.

20. Falck W. E., Nilsson K. F. Geological disposal of radioactive waste: moving towards implementation. JRC reference report. European Communities, 2009. ISBN 978-92-79-12697-0. 
21. The Swedish Radiation Protection Institute's Regulations Concerning the Final Management of Spent Nuclear Fuel and Nuclear Waste with background andcomments. SSI rapport : 2000:18. Stockholm: Swedish Radiation Protection Institute, 2000. 22. National Waste ProgrammeBAT / BPM Resource GuideGuidanceDocumentNWP-REP-100 - Issue 2. Cumbria: LLW Repository Ltd, 2018.

23. Safety case for the disposal of spent nuclear fuel at Olkiluoto. Models and data for the repository system 2012. Parts 1 and 2. POSIVA-13-1. - Eurajoki: Posiva Oy, 2013.

24. Vahlund F. et al. Model summary report for the safety assessment SR-Site. SKB-TR-14-11. - Stockholm: Swedish Nuclear Fuel and Waste Management Co., 2014.

25. Provisional Safety Analyses for SGT Stage 2. Models, Codes and General Modelling Approach. NagraTechnical Report 14-09. - Wettingen: National Cooperative for the Disposal of Radioactive Waste, 2014.

26. Kompleksnaya programma issledovaniy $\mathrm{v}$ obosnovanie dolgovremennoy bezopasnosti zakhoroneniya RAO i optimizatsii ekspluatatsionnykh parametrov : utv. 09.01.2019 Direktorom po gosudarstvennoy politike v oblasti RAO, OYAT i VE YAROO GK «Rosatom» O.V. Kryukovym [A comprehensive research program for the long-term safety assessment of RW disposal and optimization of operational parameters: approved 01/09/2019 by Kryukov O. V., Director for Public Policy on Radioactive Waste, Spent Nuclear Fuel and Nuclear Decommissioning, State Corporation Rosatom].

27. Birkholzer J. T. et al. 25 years of DECOVALEXScientific advances and lessons learned from an international research collaboration in coupled subsurface processes. International Journal of Rock Mechanics and Mining Sciences, 2019, vol. 122, p. 103995. DOI: 10.1016/j.ijrmms.2019.03.015.

28. Szőke I. et al. Comprehensive support for nuclear decommissioning based on 3D simulation and advanced user interface technologies. Journal of Nuclear Science and Technology, 2015, vol. 52, no. 3, pp. 371-387. DOI:10.1080/00223131.2014.951704.

29. RB-153-18. Rekomendatsii po obosnovaniyu vybora varianta vyvoda iz ekspluatatsii ob"ektov ispolzovaniya atomnoy energii [Recommendations on the justification of the option choice for decommissioning of nuclear facilities].

30. НП 103-17. Trebovaniya k obespecheniyu bezopasnosti punktov razmeshcheniya osobykh radioaktivnykh otkhodov i punktov konservatsii osobykh radioaktivnykh otkhodov [Requirements for ensuring the safety of special radioactive waste disposal facilities and special radioactive waste conservation facilities].
31. RB-117-16. Otsenka dolgovremennoy bezopasnosti punktov pripoverkhnostnogo zakhoroneniya radioaktivnykh otkhodov [Long-term safety assessment of near-surface radioactive waste disposal sites].

32. Perechen deystvuyushchikh attestatsionnykh pasportov programmnykh sredstv po sostoyaniyu na yanvar $2020 \mathrm{~g}$. [The list of valid software certificates. of as of January 2020] URL: https://www.secnrs.ru/ expertise/software-review/passeports_database_ january_2020.pdf.

33. Drobyshevskiy N. I., Moiseenko E. V., Butov R. A., Tokarev Yu. N. Trekhmernoe chislennoe modelirovanie teplovogo sostoyaniya punkta glubinnogo zakhoroneniya radioaktivnykh otkhodov v Nizhnekanskom massive gornykh porod [Threedimensional numerical modelling of the thermal state of the deep radioactive waste disposal facility in the Nizhnekansk granitoid massif]. Radioaktivnye othody - Radioactive Waste, 2017, no. 1, pp. 64-73.

34. Kryuchkov D. V., Boldyrev K. A. Printsipy kompleksnogo ucheta protsessov evolyutsii inzhenernykh barerov bezopasnosti pri otsenke rasprostraneniya radionuklidov za predely ob"ekta [Principles Ensuring Comprehensive Accounting of Processes Associated with Engineered Safety Barriers' Evolution: Assessing Radionuclide Spread Beyond Site Boundaries]. Radioaktivnye othodyRadioactive Waste, 2019, no. 4 (9), pp. 106-115. DOI: 10.25283/2587-9707-2019-4-106-115.

35. Blokhin A. I. et al. Programmnyy kompleks «KORIDA» dlya prognozirovaniya radiatsionnykh poley s uchetom izmeneniy kharakteristik istochnikov izlucheniya i inzhenernykh barerov bezopasnosti [Corida: A Program Package for Predicting Radiation Fields Based on the Variations in the Properties of Radiation Sources and Engineering Security Barriers]. Voprosy atomnoy nauki i tekhniki. Seriya: Matematicheskoe modelirovanie fizicheskikh protsessov - Voprosy Atomnoy Nauki i Tekhniki, series "Mathematical Modeling of Physical Processes", 2019, no. 4, pp. $78-87$.

36. Svidetel`stvo o gosregistracii programmy` dlya E`VM 2020611976. Programma dlya tryoxmernogo geofil tracionnogo i geomigracionnogo modelirovaniya (GERA/V2) [Certificate of state registration of a computer program 2020611976. Russian Federation. The program for three-dimensional geofiltration and geomigration modeling (GERA/ V2)] / Boldyrev K. A., Grigoryev F. V., Kapyrin I. V., Kopytov G. V., $\quad \mathrm{Nu}-$ zhny A. S., Plenkin A.V., Rastorguev A. V., Savelyeva-Trofimova E. A., Suskin V.V., Trofimov A. A., Utkin S. S., Vasilevsky Yu. V., Konshin I. N., Kramarenko V. K., , Nikitin K. D., Chernyshenko A. Yu., Novikov K. A., Anuprienko D. V., Neuvazhaev G. D.; 
copyright holder Russian Federation, on behalf of which stands the State Atomic Energy Corporation Rosatom. - № 2020610550; declared 01/24/2020; registered 02/12/2020; published 02/12/2020, Bull. № 2. -2 p. (in Russian).

37. Saveleva E. A. Kontseptsiya programmnogo kompleksa dlya otsenki neopredelennosti pri obosnovanii bezopasnosti punktov zakhoroneniya RAO [The concept of software complex to evaluate uncertainty in demonstration of RW disposal facility safety]. Yadernaya $i$ radiatsionnaya bezopasnost - Nuclear and Radiation Safety, 2016, no. 4, pp. 22-35.

38. Bakin R. I. et al. Programmnoe sredstvo dlya otsenki istochnika vybrosa $\mathrm{v}$ atmosferu radioaktivnykh gazov i aerozoley pri demontazhe ili razrushenii zdaniy i sooruzheniy, zagryaznennykh radioaktivnymi veshchestvami [Source Term Assessment Software for Atmospheric Releases of Radioactive Gases and Aerosols during Dismantlement or Demolition of Buildings and Structures with Radioactive Contamination]. Radioaktivnye othody - Radioactive Waste, 2019, no. 3 (8), pp. 91102. DOI: 10.25283/2587-9707-2019-3-91-102.

39. Sorokovikova O. S., Dzama D. V., Asfandiyarov D. G. Raschyotnyy kod dlya chislennogo modelirovaniya perenosa radioaktivnoy primesi v krupnykh vodnykh akvatoriyakh metodom lagranzhevykh krupnykh chastits $\mathrm{s}$ ispolzovaniem sovremennykh tekhnologiy vysokoproizvoditelnykh vychisleniy. Chast I [Computer code for numerical simulation of radioactive admixture transport in large water areas by the Lagrangian large particle method using modern highperformance computing technologies. Part 1] Preprint IBRAE no. IBRAE-2018-01. Moscow, IBRAE RAN Publ., 2018. 31 p.

40. NEA/RWM/R(2018)2. Managing Information and Requirements in Geological Disposal Programmes. Paris: OECD NEA, 2018.

41. Hammond G. E., Lichtner P. C., Mills R. T. Evaluating the performance of parallel subsurface simulators: An illustrative example with PFLOTRAN. Water resources research. 2014, vol. 50, no. 1, pp. 208-228. DOI: 10.1002/2012WR013483.

\section{Information about the authors}

Linge Igor Innokentevich, Doctor of Engineering, Deputy Director, Nuclear Safety Institute of the Russian Academy of Sciences (52, Bolshaya Tulskaya st., Moscow, 115191, Russia), e-mail: linge@ibrae.ac.ru.

Utkin Sergey Sergeevich, Doctor of Engineering, Head of Department, Nuclear Safety Institute of the Russian Academy of Sciences (52, Bolshaya Tulskaya st., Moscow, 115191, Russia), e-mail: uss@ibrae.ac.ru.

Svitelman Valentina Semenovna, PhD, Research associate, Nuclear Safety Institute of the Russian Academy of Sciences (52, Bolshaya Tulskaya st., Moscow, 115191, Russia), e-mail: svitelman@ibrae.ac.ru.

Deryabin Sergey Aleksandrovich, Senior Manager, Department for the Development and Implementation of Nuclear Legacy Remediation Programs, State Corporation «Rosatom» (24, Bolshaya Ordynka st , Moscow, 119017, Russia), e-mail: SeADeriybin@rosatom.ru.

\section{Bibliographic description}

Linge I. I., Utkin S. S., Svitelman V. S., Deryabin S. A. Numerical Safety Assessment and Optimization of Decisions on Radioactive Waste Disposal and Nuclear Decommissioning: Trends, Needs, Opportunities. Radioactive Waste, 2020, no. 2(11), pp. 85-98. (In Russian). DOI: 10.25283/2587-9707-2020-2-85-98. 